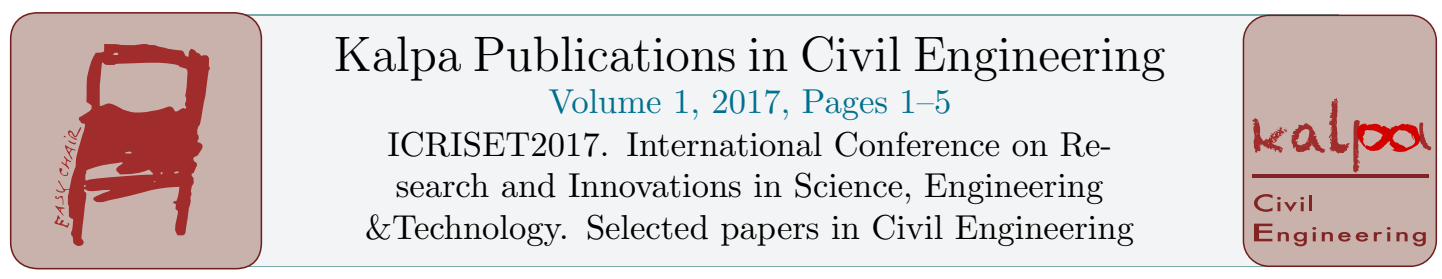

\title{
Parametric Study on Eco-Friendly Bricks
}

\author{
B. N. Dhonde ${ }^{1,2,3^{*}}$, Dr.V. R. Panchal ${ }^{1 \dagger}$ and Dr. J. N. Thakker ${ }^{\dagger \dagger}$ \\ ${ }^{1}$ Civil Engineering Department, CHARUSAT, Changa, India \\ ${ }^{2}$ Professor \& Head, Civil Engineering Department, CHARUSAT, Changa, India \\ ${ }^{3}$ Asst. professor(biotechnology) \& Head, CHARUSAT, Changa, India \\ bhavin.dhonde@gmail.com, vijaypanchal.cv@charusat.ac.in,jankithakker.bt@charusat.ac.in
}

\begin{abstract}
Every year about 1.3 trillion bricks are manufactured in, and the world of which at least $10 \%$ are made in coal fired kilns, releasing about 800 million tons of $\mathrm{CO}_{2}$ annually. Eco-friendly bricks help to reduce the emission of $\mathrm{CO}_{2}$ in environment. Another aspect is to utilize waste materials and by products such as fly-ash, rice-husk, chopped straw etc., which are cheaper and easily available. These materials should help to achieve better properties for bricks. Another aim is to reduce the shrinkage problem in present eco-friendly bricks by adding waste products and increase in the strength and serviceability of present eco-friendly bricks. In this study we utilize different materials with varying percentage to produce eco-friendly bricks with improved properties. Shrinkage of the present eco-friendly bricks was reduced by adding rice-husk (RH) and chopped-straw (CS). The highest strength of the brick was achieved.
\end{abstract}

\section{Introduction}

A brick is a building material used to make walls, pavements and other elements of masonry construction. Conventional bricks are good in durability but a drawback lies in carbon emission during baking process in kilns. So the focus is on improving the properties of non-fired clay bricks. Non-fired clay bricks are other types of bricks which do not involve burning in kilns as no carbon emission takes place. Many issues like shrinkage and strength are related to non-fired clay bricks which can be a new research area for researchers in the field.

C.D. Modhera, G.J. Joshi, D. Soni, I.N. Patel, A.K. Verma, L.B. Zala, S.D. Dhiman, D.R. Bhatt, J.M. Rathod, B.C. Goradiya, M.S. Holia and D.K. Patel (eds.), ICRISET2017 (Kalpa Publications in Civil Engineering, vol. 1), pp. 1-5 


\section{Earlier Methods}

\subsection{Bio-cementation based on ures and calcium}

For the process of bio-cementation the biogeochemical reactions are as follows:

$$
\begin{aligned}
& \qquad \begin{array}{l}
\left(\mathrm{NH}_{2}\right)_{2} \mathrm{CO}+2 \mathrm{H}_{2} \mathrm{O} \stackrel{\text { Urease }}{\longrightarrow} \mathrm{CO}_{2} \uparrow+2 \mathrm{NH}_{4} \mathrm{OH}, \\
\mathrm{CO}_{2}+\mathrm{H}_{2} \mathrm{O} \longleftrightarrow \mathrm{H}_{2} \mathrm{CO}_{3} \stackrel{\text { Carbonicanhydrase }}{\longrightarrow} \mathrm{H}^{+}+\mathrm{HCO}_{3}{ }^{-} \longleftrightarrow 2 \mathrm{H}^{+}+\mathrm{CO}_{3}{ }^{2-}, \\
\mathrm{CaCl}_{2}+\mathrm{H}_{2} \mathrm{CO}_{3} \longrightarrow \mathrm{CaCO}_{3} \downarrow+2 \mathrm{HCl}, \\
2 \mathrm{HCl}+2 \mathrm{NH}_{4} \mathrm{OH} \longrightarrow 2 \mathrm{NH}_{4} \mathrm{Cl}+2 \mathrm{H}_{2} \mathrm{O},
\end{array} \\
& \\
& \text { Total } \\
& \left(\mathrm{NH}_{2}\right)_{2} \mathrm{CO}+2 \mathrm{H}_{2} \mathrm{O}+\mathrm{CaCl}_{2} \stackrel{\text { Urease and Carbonicanhydrase }}{\longrightarrow} \mathrm{CaCO}_{3} \downarrow+2 \mathrm{NH}_{4} \mathrm{Cl}
\end{aligned}
$$

In this process, calcium carbonate is produced in form of calcite. This calcite helps to make bonds between the soil particles ${ }^{[1]}$. Earlier eco-friendly bricks were produced on the basis of these phenomena

\subsection{Stabilization of the soil}

This is a process to increase the soil's resistance against different weather conditions with different solutions. The soil stability can be improved by reduction of the internal movements of the soil particles. Addition of fibers to soil can reduce the magnitude of free shrink and swell movements. Soil can also be stabilized by cementing the particles of the soil together and by making the soil waterproof or at least less permeable to moisture. These phenomena can help to reduce the shrinkage and improve strength of previous eco-friendly bricks.

\section{Experimental Work}

Previously eco-friendly bricks were produced on the basis of bio-cementation process. But we added different materials such as chopped-straw, rise husk, lime and fly-ash as additives in eco-friendly bricks. The mix proportion was made by referring different references ${ }^{[1-6]}$.

\subsection{Materials and mix design}

Mud is the main material for brick making. Soil is selected for this experiment is containing $60 \pm 3 \%$ sand and $40 \pm 5 \%$ (silt + clay) which is calculated by weight sieve analysis. The plastic limit of the soil was measured nearer 7 to 8 . Rice husk and chopped-straw was used as fiber for the eco-friendly bricks. It was utilized to decrease movements of soil particles in brick. Soil was blended with the fibers with different concentration, as shown in Table 1.

\begin{tabular}{|c|c|c|}
\hline Sr. No. & $\begin{array}{c}\text { Soil percentage } \\
\mathbf{( \% )}\end{array}$ & $\begin{array}{c}\text { Rise husk + Chopped } \\
\text { straw percentage (\%) }\end{array}$ \\
\hline $\mathbf{1}$ & $99.5 \%$ & $0.5 \%$ \\
\hline $\mathbf{2}$ & $99.0 \%$ & $1.0 \%$ \\
\hline $\mathbf{3}$ & $98.5 \%$ & $1.5 \%$ \\
\hline
\end{tabular}

Table 1: Mix proportion of $(\mathrm{RH}+\mathrm{CS})$ 
Another mix is added with $1 \%$ constant dosage of fiber and fluctuating percentage of fly-ash and lime in the blend. The trial mix of the soil for the produced brick was as shown in Table 2.

\begin{tabular}{|c|c|c|c|c|}
\hline Sr. No. & $\begin{array}{c}\text { Soil } \\
\text { percentage } \\
\mathbf{( \% )}\end{array}$ & $\begin{array}{c}\text { Fly-ash } \\
\text { percentage (\%) }\end{array}$ & $\begin{array}{c}\text { Lime percentage } \\
\mathbf{( \% )}\end{array}$ & RH+CS percentage (\%) \\
\hline Type 1 & $94 \%$ & $1 \%$ & $4 \%$ & $1 \%$ \\
\hline Type 2 & $94 \%$ & $2 \%$ & $3 \%$ & $1 \%$ \\
\hline Type 3 & $94 \%$ & $3 \%$ & $2 \%$ & $1 \%$ \\
\hline
\end{tabular}

Table 2: Mix proportion of lime and fly-ash

Water was added to the mix for wetting the mixture by ratio of $(5: 1) \mathrm{w} / \mathrm{v} \%$ of soil. Micro-organism was added to water with proportion of $0.1 \%(\mathrm{v} / \mathrm{w})$.

\subsection{Blending and casting specimen}

In the wake of adding all the added substance items to the blend, next stride was mixing of blend. Levelled and cleaned surface was required for the mixing technique. Blending of the mix was done by hand mixing. The mixed blend was kept at room temperature for proper mixing until the appropriate consistency was achieved. The bricks mold having an inner dimension of $230 \mathrm{~mm} \times 110 \mathrm{~mm} \times 70 \mathrm{~mm}$ $(\mathrm{L} \times \mathrm{W} \times \mathrm{H})$ was used. The brick mold was selected as per specifications of Indian standards for burnt bricks (IS 1077:1992).

\subsection{Drying and testing}

Drying process of the casted eco-friendly bricks is different than the conventional bricks. The casted bricks were dried under sun for $7^{\text {th }}, 14^{\text {th }}$ and $21^{\text {st }}$ days ${ }^{[3]}$. These bricks were tested for $7^{\text {th }}, 14^{\text {th }}$ and $21^{\text {st }}$ days for the compressive strength test. The testing of the bricks was conducted by referring IS 3495:1992. For every result total 5 numbers of brick were tested.

\section{Result And Discussion}

After testing and analysis of the bricks having new added properties, we got the following results. All the results were taken in multiple of five:

\subsection{Reduction of shrinkage}

\begin{tabular}{|c|c|c|}
\hline Sr. No. & Percentage of RH+CS (\%) & $\begin{array}{c}\text { Percentage of shrinkage in brick } \\
\text { (\%) }\end{array}$ \\
\hline 1 & 0.5 & $7.20 \pm 0.69$ \\
\hline 2 & 1.0 & $4.21 \pm 0.24$ \\
\hline 3 & 1.5 & $3.97 \pm 0.16$ \\
\hline
\end{tabular}

Table 3: Average shrinkage results 
From above Table we can see that with increase in RH + CS \%, we found reduced shrinkage which eventually increased the strength.

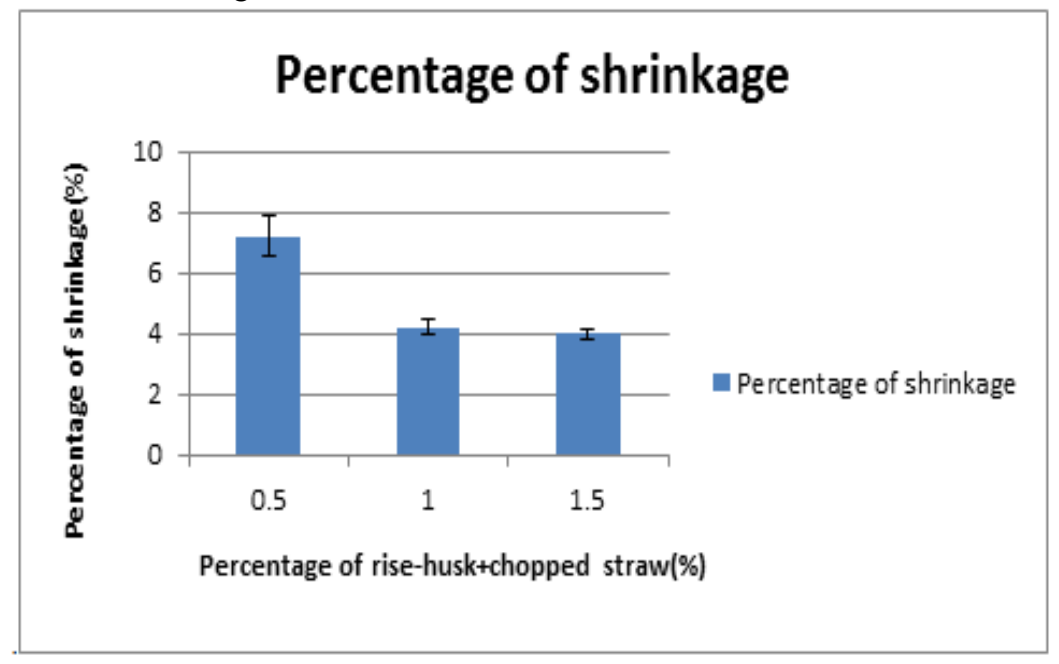

Figure 1: Shrinkage reduction (percentage of $(\mathrm{RH}+\mathrm{CS})$ vs percentage of shrinkage)

In this experiment bricks with $1.5 \%$ of rise husk + chopped straw show excessive cracking.

\begin{tabular}{|c|c|c|}
\hline Sr. No. & Percentage of $\mathrm{RH}+\mathrm{CS}(\%)$ & Compressive strength $\left(\mathrm{N} / \mathrm{mm}^{2}\right)$ \\
\hline 1 & $0.5 \%$ & $2.97 \pm 0.201$ \\
\hline 2 & $1.0 \%$ & $3.44 \pm 0.047$ \\
\hline 3 & $1.5 \%$ & - \\
\hline
\end{tabular}

Table 4: Compressive strength results with $(\mathrm{RH}+\mathrm{CS})$

Table 4 shows that with increase in addition of $(\mathrm{RH}+\mathrm{CS})$ fiber, compressive strength of the brick is also increased.

\subsection{Strength improvement}

After testing specimens with different mix we noticed that the strength of the eco-friendly brick is considerably increased.

\begin{tabular}{|c|c|c|c|}
\hline $\begin{array}{c}\text { Mix } \\
\text { design type }\end{array}$ & $\begin{array}{c}\text { Strength on } \\
\mathbf{7}^{\text {th }} \mathbf{d a y}\left(\mathbf{N} / \mathbf{m m}^{2}\right)\end{array}$ & $\begin{array}{c}\text { Strength on } \\
\mathbf{1 4}^{\text {th }} \mathbf{d a y}\left(\mathbf{N} / \mathbf{m m}^{\mathbf{2}}\right)\end{array}$ & $\begin{array}{c}\text { Strength on } \\
\mathbf{2 1}^{\text {st }} \mathbf{d a y}\left(\mathbf{N} / \mathbf{m m}^{\mathbf{2}}\right)\end{array}$ \\
\hline Type-1 & $4.1982 \pm 0.240$ & $4.2378 \pm 0.241$ & $4.2764 \pm 0.219$ \\
\hline Type-2 & $4.087 \pm 0.203$ & $4.14518 \pm 0.168$ & $4.1976 \pm 0.181$ \\
\hline Type-3 & $4.0346 \pm 0.142$ & $4.0492 \pm 0.156$ & $4.0134 \pm 0.194$ \\
\hline
\end{tabular}

Table 5: Compressive strength results

From the Table 5 we can see that the strength of the eco-friendly brick is highest with $4 \%$ of lime and $1 \%$ of fly-ash. 


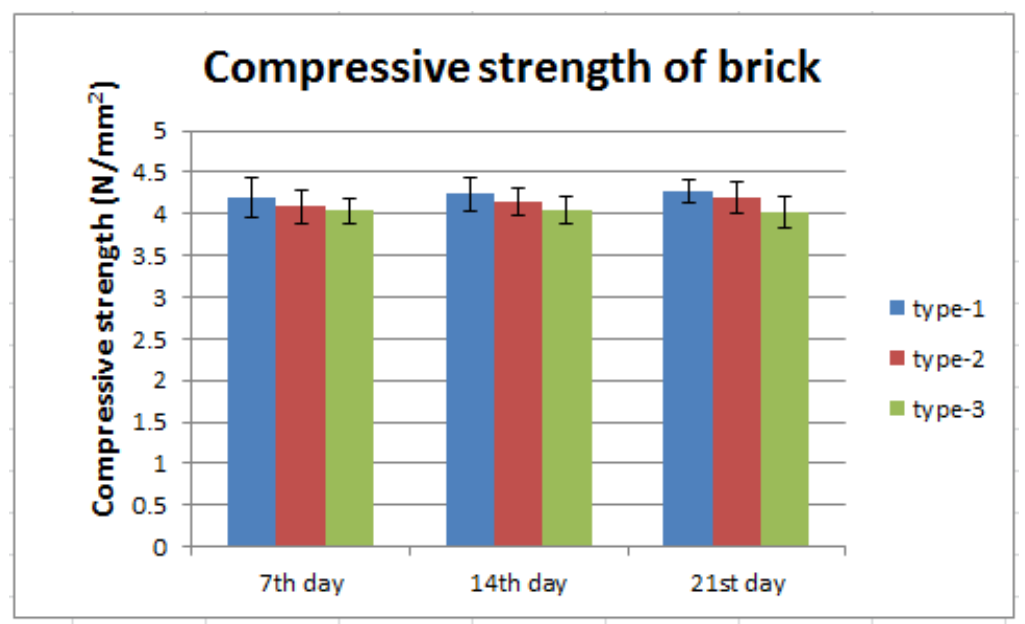

Figure 2 : Compressive strength of the brick with varying types (day of testing vs compressive strength $(\mathrm{N} / \mathrm{mm} 2))$

Above Figure shows the compressive strength of the bricks with varying types of bricks on $7^{\text {th }}, 14^{\text {th }}$ and $21^{\text {st }}$ day with errors.

\section{Conclusion}

The conclusion made from the experimental work that adding fibers (RH+CS) to eco-friendly bricks helped to reduce the shrinkage of the bricks. However at $1.5 \%$ of $(\mathrm{RH}+\mathrm{CS})$, the brick shows excessive cracks. Strength of the brick was also noticeably increased. The optimum dosage of the fiber (RH+CS) is $1 \%$. After addition of lime and fly-ash type- 1 mix gave highest strength on $21^{\text {st }}$ day. It is also found that the addition of lime to the mix is helping to improve strength. All results show that after $7^{\text {th }}$ day there was no major change in the strength results. So it is also conclude that once the bricks become dry, their strength do not change greatly.

\section{References}

Çiçek, T. \&. (2015). Use of fly ash in production of light-weight building bricks. Construction and Building Materials, 521-527.

Dhandhukia, P. G. (2013). Soil property apotheosis to corral the finest compressive strength of unbaked adobe bricks. Construction and Building Materials, 948-953.

Enokela, O. S. (2012). Strength analysis of coconut fiber stabilized earth for farm structures. Int $J A d v$ Res Tech, 1-7.

Naganathan, S. M. (2015). Performance of bricks made using fly ash and bottom ash. Construction and Building Materials, 576-580.

Serrano, S. B. (2016). Use of by-products as additives in adobe bricks: Mechanical properties characterisation. Construction and Building Materials, 105-111.

Sumathi, A. \&. (2015). Compressive Strength of Fly Ash Brick with Addition of Lime, Gypsum and Quarry Dust. International Journal of ChemTech Research, 28-36. 